\title{
GEOARCHAEOLOGICAL CONTEXT OF ARCHAEOLOGICAL SITE AT KRAKÓW-STRADOM (SOUTHERN POLAND)
}

DOI: http://dx.doi.org/10.18509/GBP.2019.04

UDC: 911.5:902.2(438)

\author{
Tomasz Kalicki ${ }^{1}$ \\ Marcin Frączek ${ }^{1}$ \\ Radosław Czerniak ${ }^{2}$ \\ ${ }^{1}$ Institute of Geography, Jan Kochanowski University in Kielce, Poland \\ ${ }^{2}$ Student Science Club of Geomorphologists „Złoty Bażant”, Jan Kochanowski University in \\ Kielce, Poland
}

\begin{abstract}
The Vistula flood plain has a very complicated structure both in horizontal and vertical layout. This applies to both the facies' formation of the sediments and their stratigraphy. Within the site, two areas with distinctly different types of sediments can be distinguished (Fig. 6). The first refers to the extensive zone of sandy-gravel channel sediments from Late Glacial in the lower part and Subatlantic in the upper part. The second area includes the oxbow lake sequences. The Early Atlantic series, both the channel and the oxbow lake sequences of „Old Vistula”. The study confirmed the position suggested by Bąkowski [11], that the „Old Vistula" has been excavated, taking into account previous morphology. It was probably a lowering of the Early Atlantic abandoned channel.
\end{abstract}

Keywords: geoarchaeology, “Old Vistula”, Holocene evolution, Kraków

\section{INTRODUCTION}

The Vistula, after passing the Kraków Gate, flows through the western part of the Sandomierz Basin. Erosion relief developed on the Miocene clays is covered by diverse Quaternary sediments. From the north, the valley is limited by the erosion edge of the Proszowice Upland. There are two Pleistocene terraces of the Vistula (8-12 and 15-25 m above the river level) covered with the Vistulian loess [1], [2] and also two Pleistocene alluvial fan of the Vistula tributaries - Prądnik and Dłubnia, without loess cover. The drainage network of these terraces is formed by the few valleys of permanent creeks most often flowing from Upland and branched dry systems of fluvial-denudational valleys (dellen).

Wide (3-7 km) floodplain, 4-5 $\mathrm{m}$ above the level of the Vistula river, has a very complicate structure [3], [4]. In the marginal parts remained fragments of the Young Pleniglacial and Late Glacial braided alluvial plain. They have been preserved mainly in the wide depression of Drwien and Drwinka rivers in the south and in small fragments under the edge of the loess terraces and also between meander belts downstream of Niepołomice. In the remaining areas of the valley bottom there are numerous oxbow lakes of different age (so-called in Polish "wiśliska"). Their systems indicating the meandering of the Vistula in the Holocene - lateral migration and avulsion of riverbed [5], [3], [4], [6], [7]. Alluvial sediments of floodplains are up to 4-15 $\mathrm{m}$ thick and has finning upward sequence. There are sands with gravels in the bottom (lag and channel deposits), sands in the middle (point bar deposits) and layer of silts and clays (overbank deposits) in the top, coarser near the river and finer far from the riverbed in the backswamps [3], [8]. 
The southern margin of the valley creates edge of Gdów Upland which is dissected by small Vistula tributaries. At the exit of these valleys arose alluvial fans, which the oldest deposits interfinger with the Young Pleniglacial alluvia of braided Vistula river. However, their intense accumulation is related to the Neoholocene (Subboreal, Subatlantic) because these fans were deposited on the overbank sediments of the Holocene backswamps [9].

\section{LOCATION AND STATE OF STUDY}

Kraków-Stradom site is located in the center of Kraków on Stradom street which connected two independent cities, Kraków and Kazimierz, in the Middle Ages. This is the zone below the edge of the Pleistocene alluvial fan. The fan built alluvial sands and gravels of the Vistula river and its tributary Prądnik river. This fan was originally elevated about 5-10 $\mathrm{m}$ above the Vistula flood plain. This protected him against inundation during the floods of the main river and its tributaries. Medieval Kraków was located on it and at the foothill of the limestone horst with the royal castle on the Wawel Hill (Fig. 1, 2).

The bottom of the valley was a flooded area, and probably in the early Middle Ages, a series of depressions and wetlands (with peat accumulation) was located under the edge of the fan [10]. They could also be used periodically or flooded by the Prądnik (Białucha) river. At that time this tributary was flowing into the Vistula river which separated Wawel Hill from Skałka horst and Kazimierz town [11], [12], [13], [14]. A clear phase of an increase of flood frequency occurred in the $9^{\text {th }}-10^{\text {th }}$ century and it was associated with the cooling and humid climate [3], [15]. Its traces have been found, among others at Okó1 [16], [17]. It caused a rise of groundwater level and additional "inundation" of zone of the Vistula flood plain under the edge of the Pleistocene fan. Layers of overbank deposits in the peats indicate that the Vistula flooded the bottom of the valley in the following centuries and this zone was a backswamp.

\section{AIM AND METHODS OF STUDY}

Geomorphological and geological studies were carried out as part of archaeological rescue research. The main goal was to determine the geoarchaeological context of the site and its stratigraphy.

During on-site fieldwork, a prospection and lithofacies description of the exposed sediments were carried out. Three profiles were selected for detailed grain size analyses (sieve method) (Fig. 3). Also, 8 samples were taken for OSL dating, but the results were obtained only from 4 samples (4 others samples due to physical properties have not been analyzed). The analysis of grain size and determination of the age of alluvia was carried out in the Scientific and Didactic Laboratory, Institute of Geography, the Jan Kochanowski University in Kielce, Poland. 


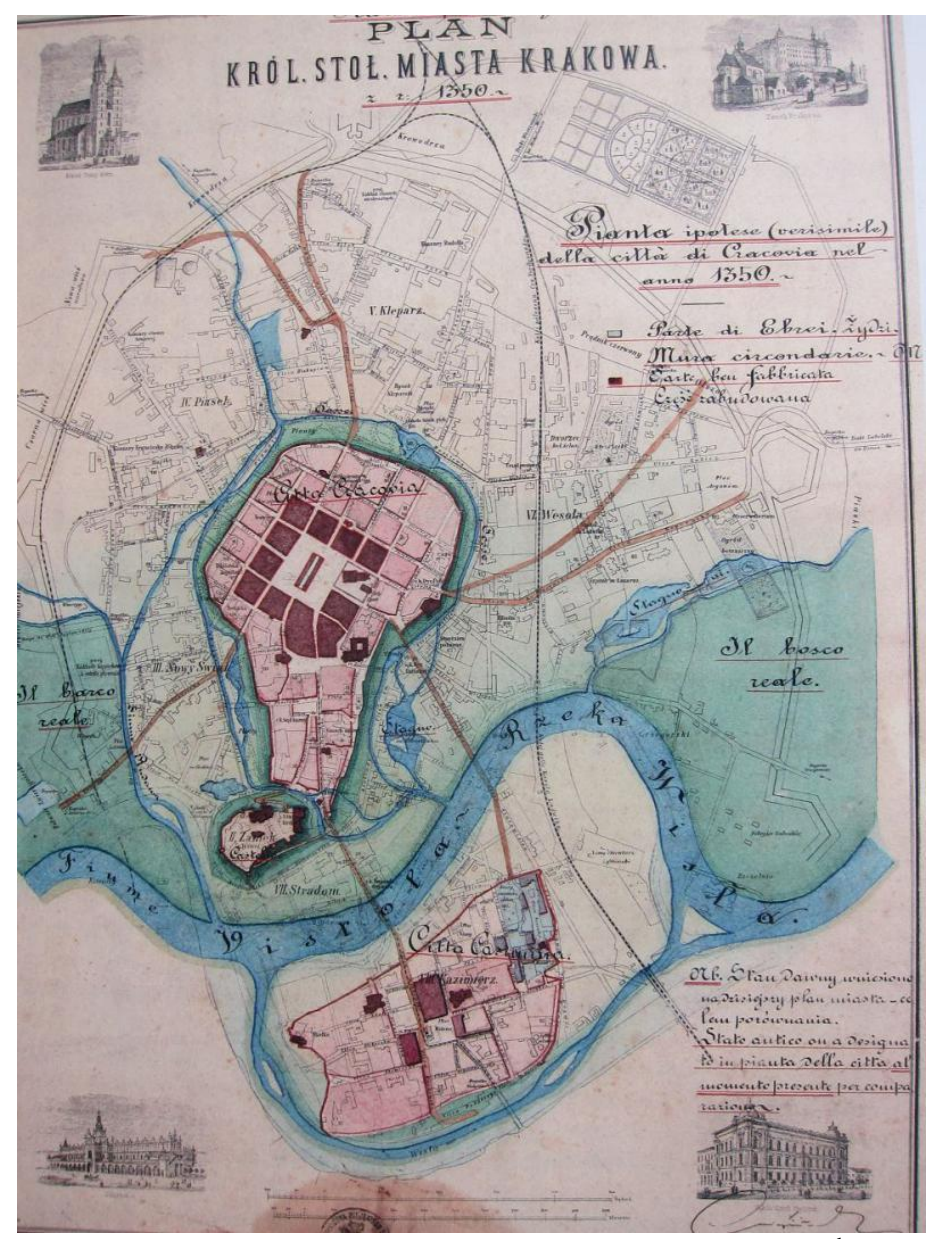

Figure 1. Hydrographic network near Kraków in $14-15^{\text {th }} \mathrm{c}$.

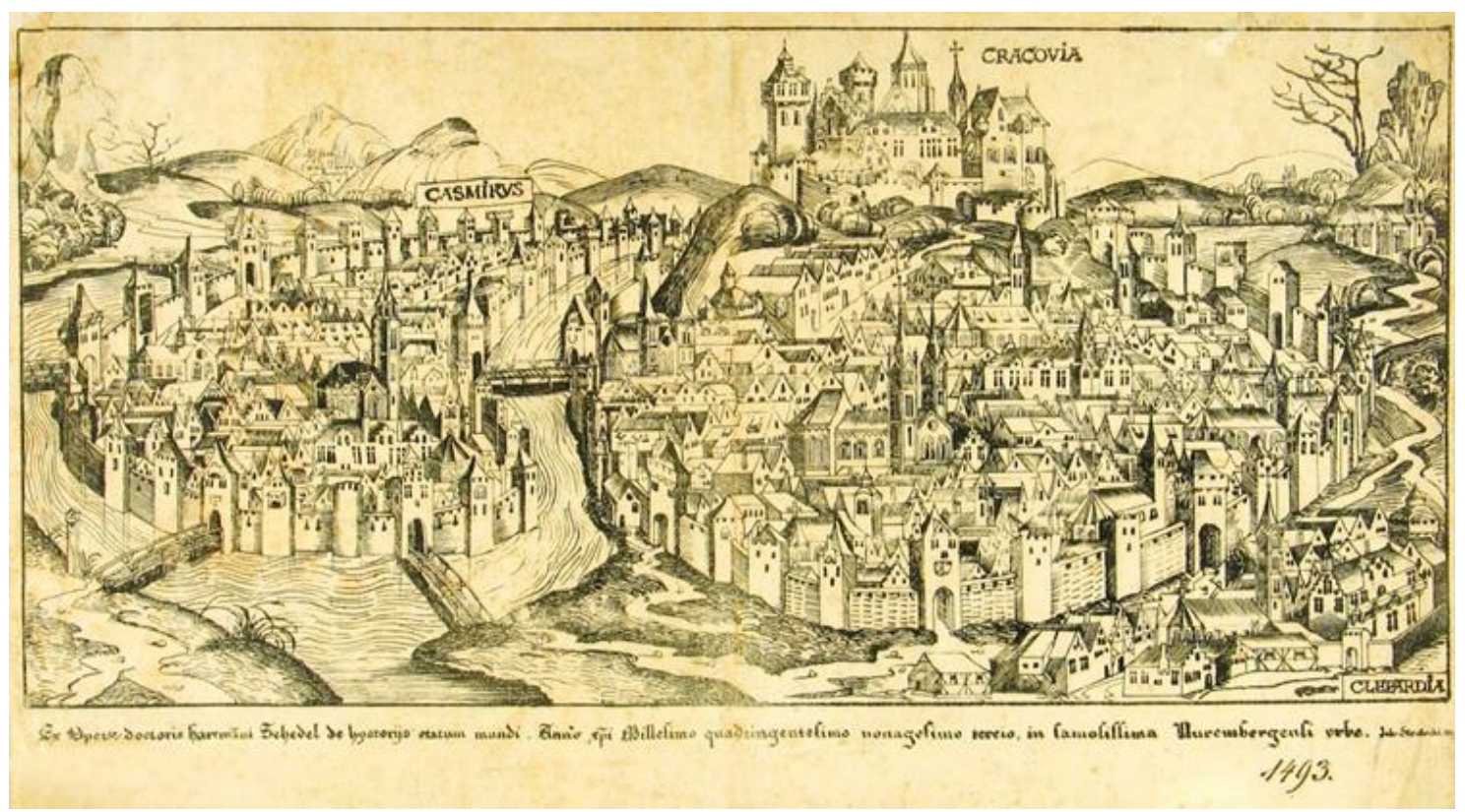

Figure 2. Panoramic view of Kraków and Kazimierz towns with two riverbeds of the Vistula river in 1493 


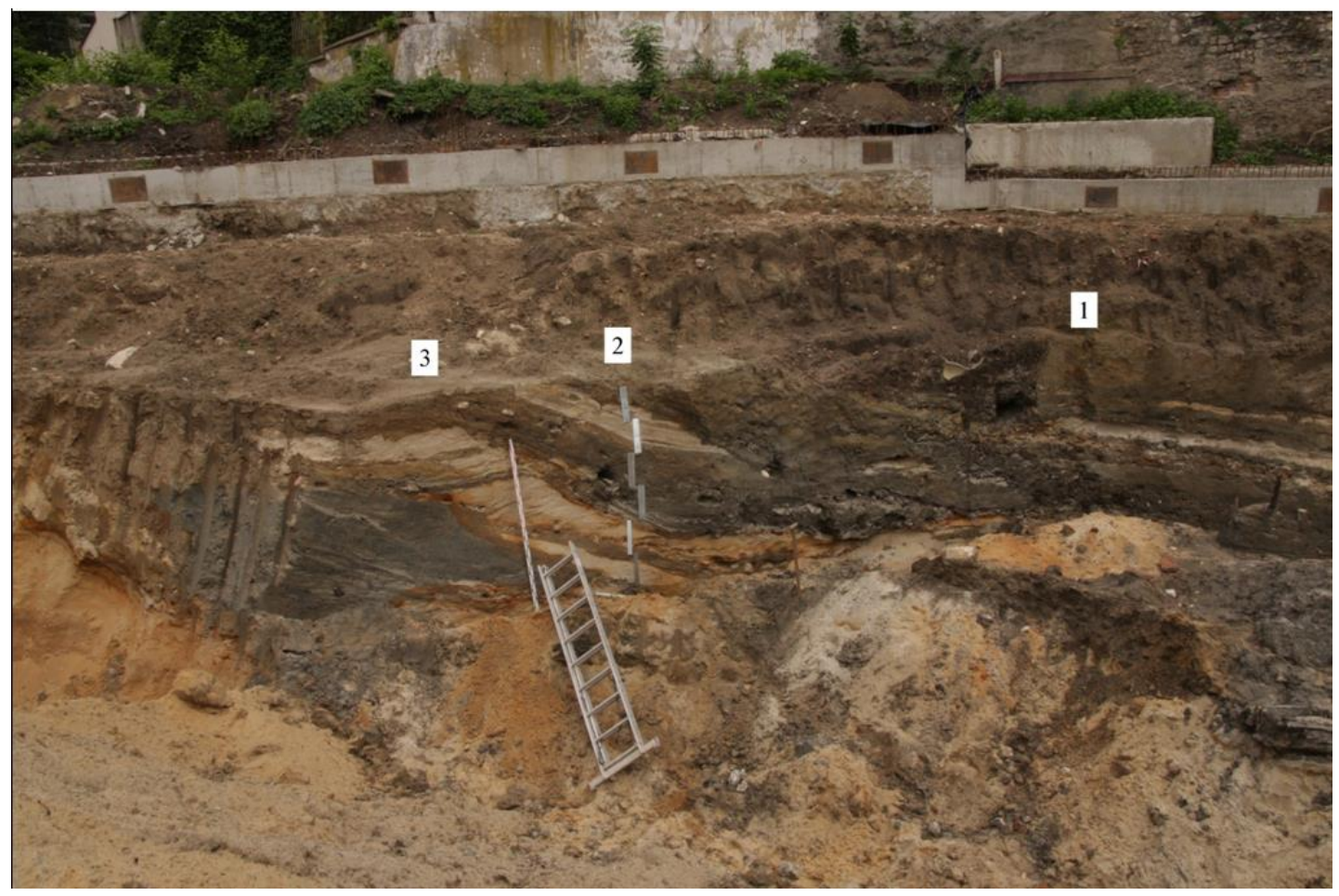

Figure 3. Location of study profile in abandoned channel fill of the Vistula river

\section{RESULTS}

The Stradom 1 profile represents the sediments of the youngest fill of abandoned channel (Fig. 3). In the lower part were found 2 five-meter piles and several smaller wooden piles. The piles were dendrochronologically analyzed by M. Krappiec, as a result of which the date of tree decay was determined for the $16^{\text {th }}$ century. Four phases of accumulation, connected with floods, are marked within fill. Each of these phases begins with a layer of coarse-grained sandy-gravel deposits. The coarsest $(\mathrm{Mz}=0.9 \mathrm{phi})$, very poorly sorted, occur in the bottoms of the first, the lowest and the forth, the highest member (Fig. 4). These are the two strongest flood events.

The Stradom 2 profile represents sediments of the youngest fill of abandoned channel (up to $210 \mathrm{~cm}$ depth) and lower point bar deposits (below $210 \mathrm{~cm}$ depth) which are OSL dated at $5.6 \pm 0.8 \mathrm{ka}$ (UJK-OSL-93)(Fig. 5).

The Stradom 3 profile represents sediments of the upper sand-gravel point bar deposits of the older cut and fill (up to $100 \mathrm{~cm}$ depth) and the oldest fill of the oxbow lake (depth below $100 \mathrm{~cm}$ ). The lowest sample already includes channel deposits below the bottom of the abandoned channel was OSL dated at $2.5 \pm 0.4 \mathrm{ka}$ (UJK-OSL-94)(Fig. 5).

In the northern part of the site, towards the edge of the Prądnik river fan, a vast area of sand-gravel point-bar deposits with the lag levels. The lower sample from sandy sediments directly above the gravel lag channel deposits was OSL dated at $11.8 \pm 1.8 \mathrm{ka}$ (UJK-OSL-91). The upper sample from sandy point bars sediments and above the next gravel layer - channel lag deposits, is much younger - $2.9 \pm 0.4 \mathrm{ka}$ (UJK-OSL-92)(Fig. $6)$. 


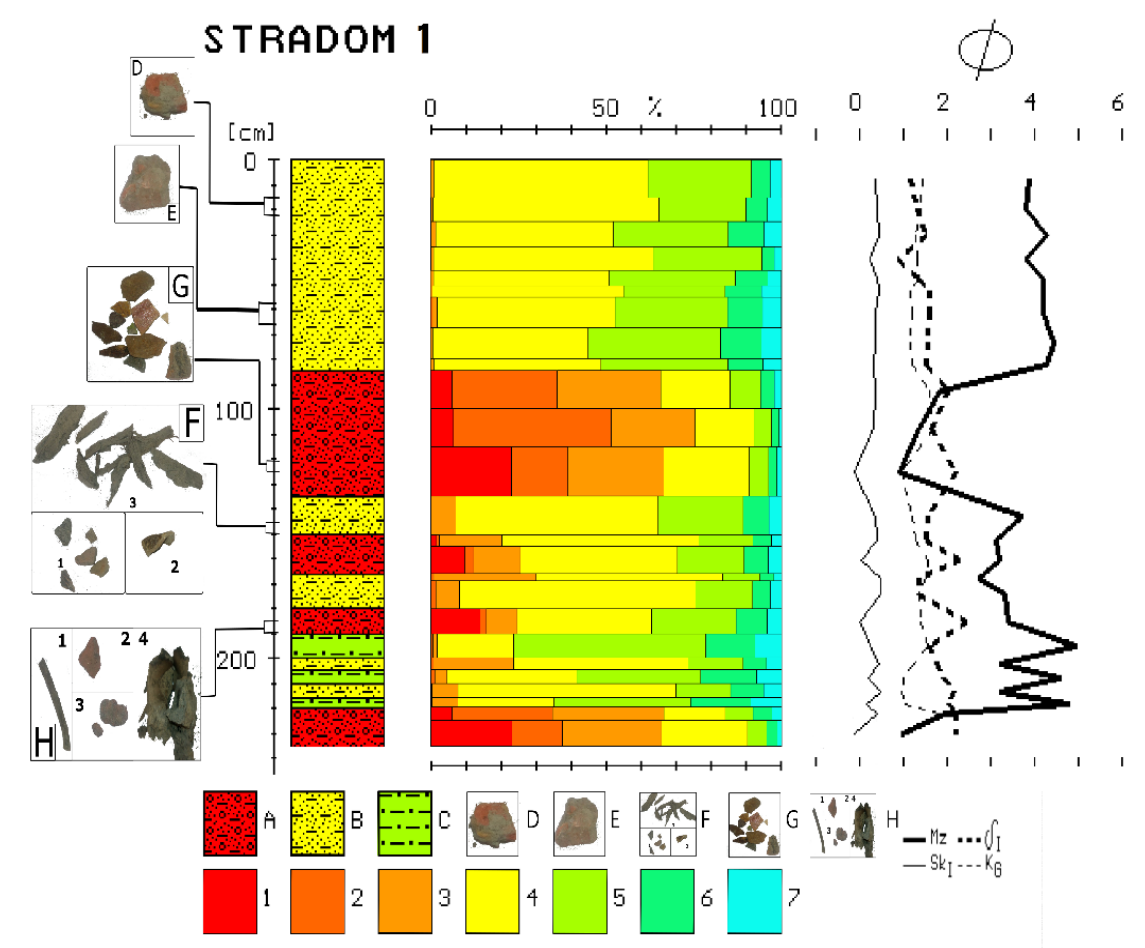

Figure 4. Lithology, grain size after [18] distribution parameters of Stradom I profile

Litology: A - silty sands with single gravels, B - silty sands, C - sandy silts, D - a piece of brick, E - a piece of brick, F - 1) parts of pottery; 2) part of bone; 3) part of wood, G - parts of potter, H - 1) rib bone species unknown; 2) parts of pottery; 3 ) a piece of brick; 4) burned clay,

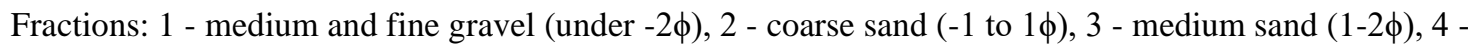

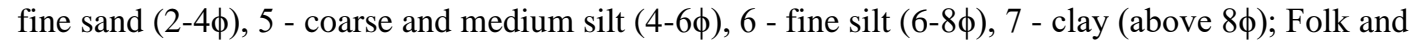
Ward's distribution parameters: $\mathrm{Mz}$ - mean diameter, $\delta 1$ - standard deviation (sorting), Skl - skewness, $\mathrm{KG}$ - kurtosis

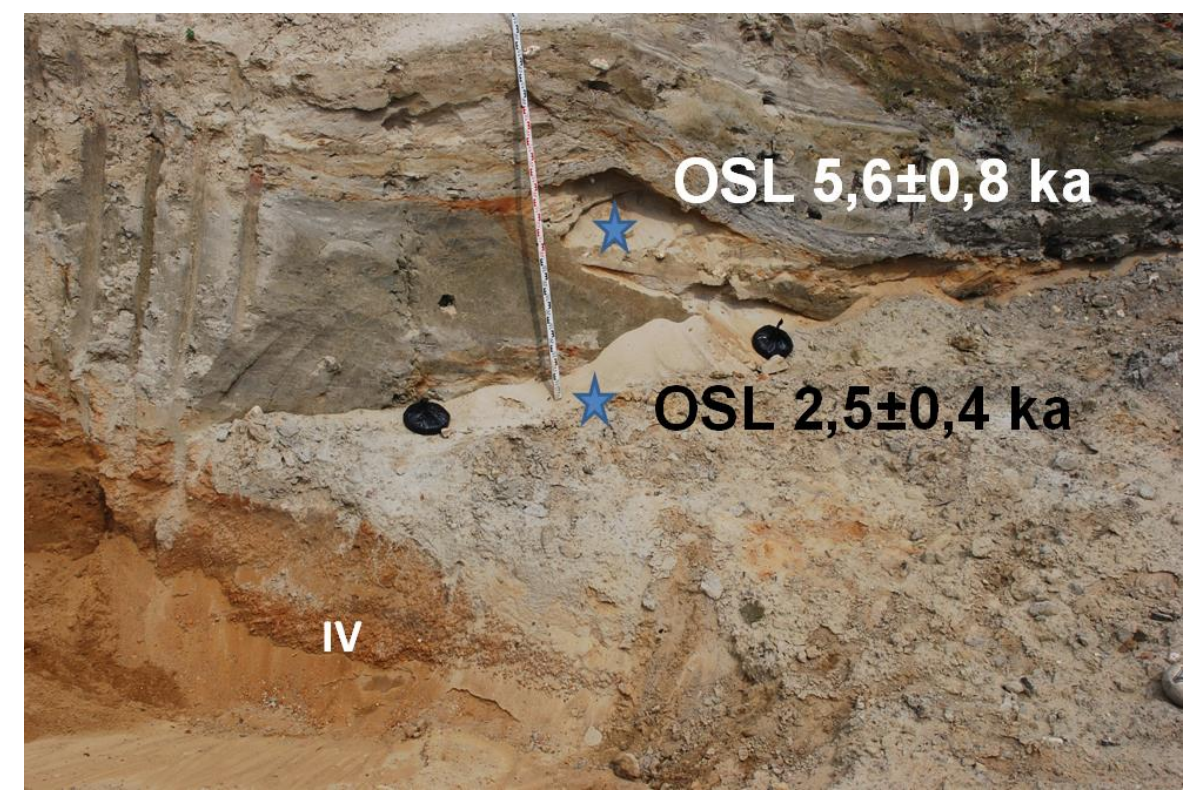

Figure 5. Sediments of older cut and fill with OSL dating and place of sampling Str IV 


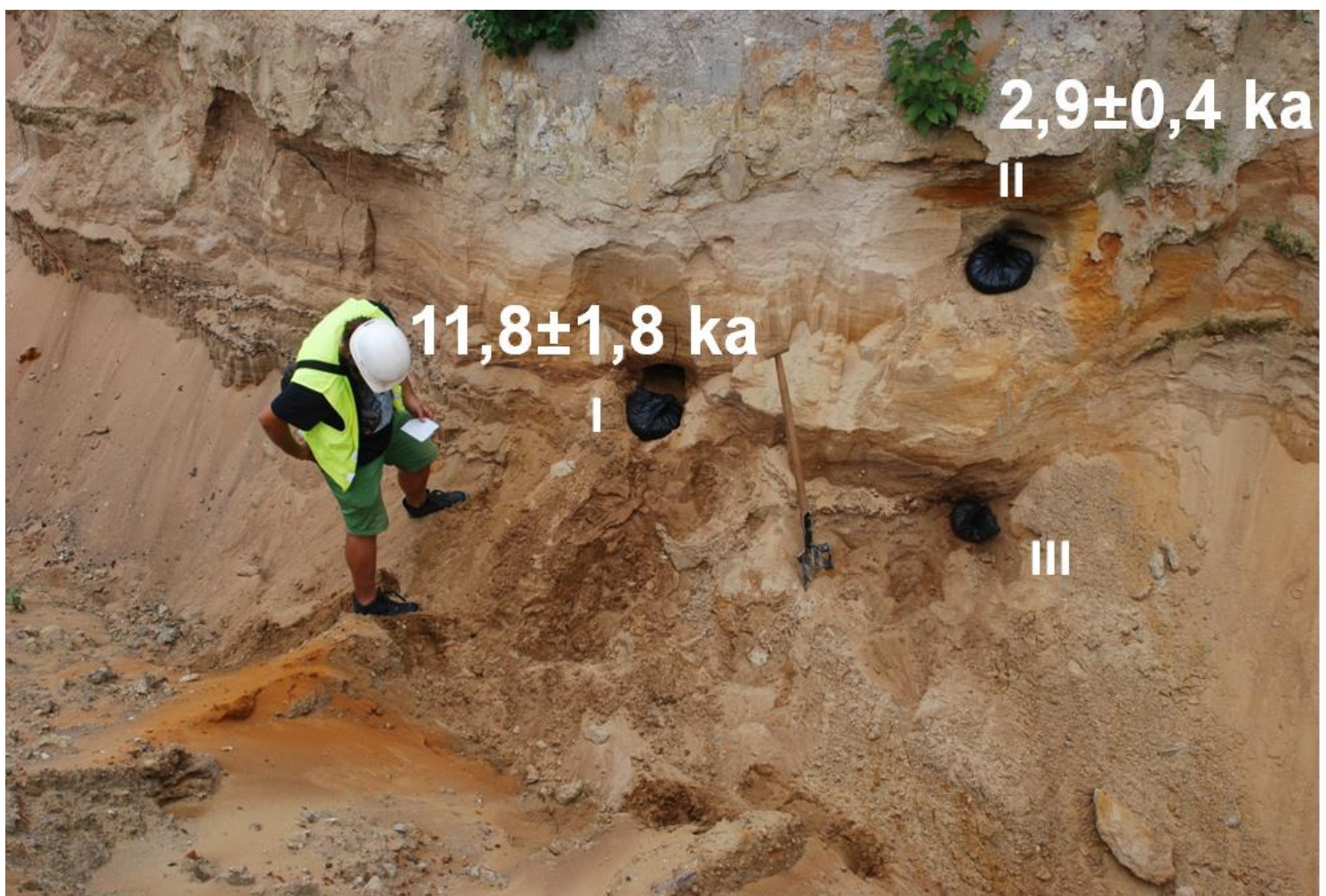

Figure 6. Cross bedded sandy-gravel channel sediments, sampling Str I, II, III and results of OSL dating

\section{DISCUSSION}

Within the site, two areas with distinctly different types of sediments can be distinguished (Fig. 7). The first refers to the extensive zone of sandy-gravel channel sediments. In the vertical profile of this area, two different series of sediments can be separated. In the lower part, there is a Late Glacial series, dated OSL, for about 12,000 years. This series is only exposed in the upper part. Therefore, it is difficult to say whether these sandygravel sediments were deposited by the meandering or even braided river. Earlier results indicate that in this period there has been a transformation of the Vistula river from the braided river to large meanders (macromeanders) [3], [4]. The river probably flowed meandering riverbed as confirmed by slightly curved undercut the Pleistocene fan of Prądnik river between Grodzka street and Rondo Mogilskie and the large palaeochannel fill at Rondo Mogilskie [19], [3], [4]. Above the Late Glacial series, there are a fully developed series of channel sediments (lag, point-bar deposits). This series was accumulated at the end of Subboreal and beginning of the Subatlantic periods (between 2.9 and $2.5 \mathrm{ka}$ years (OSL dating). At that time, the Vistula riverbed was lateral migrated southwards and it was cut off about 2,500 years ago. At the first stage, the oxbow lake was filled with quite homogeneous silty sands with few sandy layers. This indicates stable sedimentation conditions however with contact with the active Vistula riverbed. In the second stage, after the disappearance of river flows, began massive accumulation of sandy silts.

The second area includes the oxbow lake sequences. The Early Atlantic series, both the channel and the oxbow lake, are undercut by the series fill the channel of the "Old / Small" Vistula river. Whether this undercutting was originally anthropogenic is unknown, because it was clearly transformed by natural processes. This could took place during the period of functioning of the "Old Vistula" as the main channel from the $14^{\text {th }}$ to the $17^{\text {th }}$ 
century. At that time, during the floods, the banks of the river were remodelled, as evidenced by historical records [11]. The fact that there was not only bank erosion but also bottom erosion is demonstrated by the OSL date of around 5.5 ka years from point bar deposits. Such an old date indicates that into young sediments could be also included an older sediments, probably the Late Glacial, under the Subatlantic series.

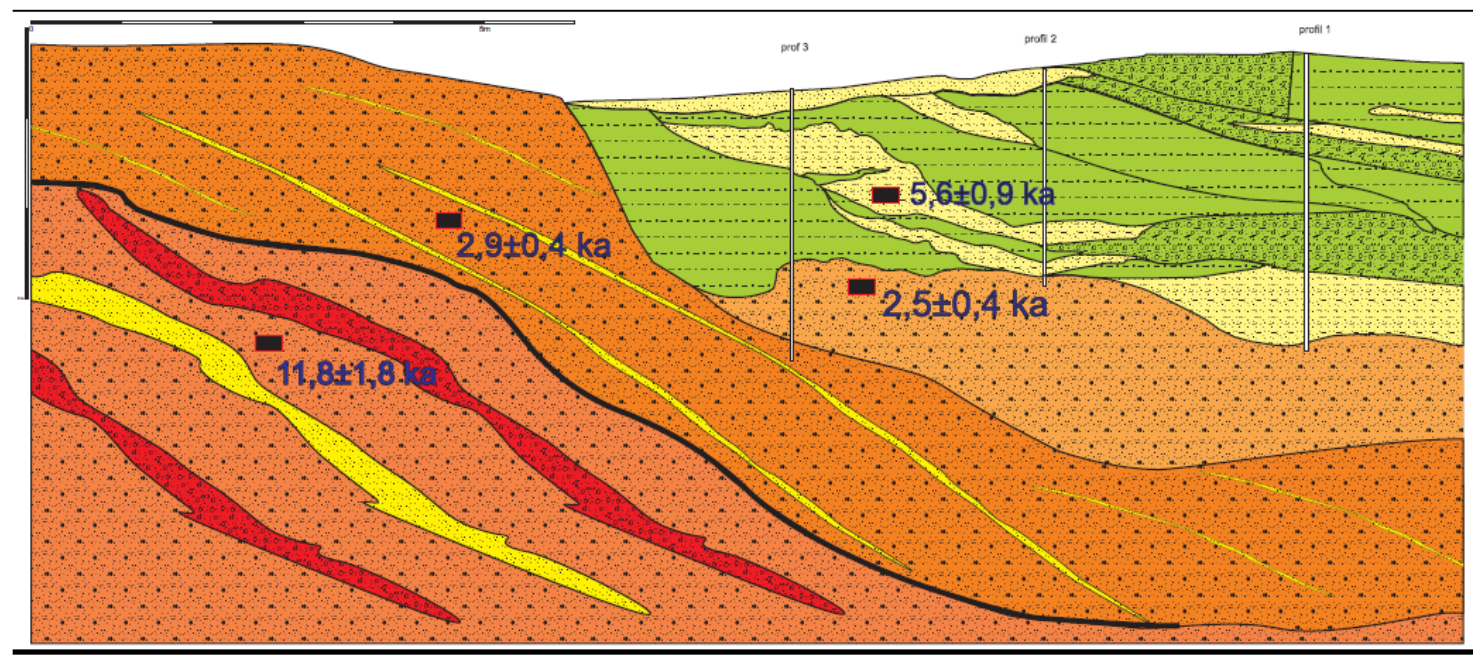

Figure 7. Schematic litho-stratigraphic cross-section of Kraków-Stradom site

Subsequent fill of the "Old Vistula" occurred initially in quite stable sedimentary conditions (older fill), then these conditions have changed definitively into a high energy environment (the youngest fill). This was probably related to the gradual shift of the main Vistula riverbed to Zakazimierka (channel to the south from Kazimierz town). Initially, it was possible to gradually narrowing of the "Old Vistula" riverbed by inclined southward silty sands with finning upward sequence accumulated in four phases (older fill of abandoned channel). This could took place in post-maximum phase of the floods when "Old Vistula" was still functioning as the main Vistula riverbed. The youngest fill of abandoned channel should be associated with the period after the $16^{\text {th }}$ century when Zakazimierka became more and more important as the main riverbed. Only waters of large floods to get into, located higher ("suspended" in relation to the main riverbed), the "Old Vistula". These waters accumulated much coarser, sandy-gravel deposits. The riverbed was filled in 4 stages. The last one with thick sediments can probably be associated with the flood of 1813. It caused almost complete "silting" of the "Old Vistula", which is visible on old maps in the form of a small stream imitating the course of the former riverbed. "Old Vistula" is finally filled up at the end of the $19^{\text {th }}$ century and Planty Dietlowskie were created in its place.

The study confirmed the position suggested by Bąkowski [11], that the „Old Vistula" has been excavated, taking into account previous morphology. It was probably a lowering of the Early Atlantic abandoned channel.

\section{CONCLUSIONS}

The results of the research at the Kraków Stradom site fully confirmed previous results [3], [4]. The Vistula flood plain has a very complicated structure both in horizontal and vertical layout. This applies to both the facies' formation of the sediments and their stratigraphy. 


\section{REFERENCES}

[1] Tyczyńska M. Rozwój geomorfologiczny terytorium miasta Krakowa, Zeszyty Naukowe UJ, Prace Geograficzne 17, 1968.

[2] Gębica P. Przebieg akumulacji rzecznej w górnym vistulianie w Kotlinie Sandomierskiej, Prace Geograficzne 193, 2004.

[3] Kalicki T. The evolution of the Vistula river valley between Cracow and Niepołomice in late Vistulian and Holocene times, [in:] Evolution of the Vistula river valley during the last 15000 years, part IV, Geographical Studies, Special Issue 6, pp 11-37, 1991.

[4] Kalicki T. Zapis zmian klimatu oraz działalności człowieka i ich rola w holoceńskiej ewolucji dolin środkowoeuropejskich, Prace Geograficzne, vol. 204, 2006.

[5] Kalicki T. Holoceńskie generacje paleomeandrów Wisły w rejonie Krakowa, Kwartalnik Akademii Górniczo-Hutniczej, Geologia, vol. 17, no. 1-2, pp 25-66, 1991.

[6] Starkel L., Gębica P., Niedziałkowska E. \& Podgórska-Tkacz A. Evolution of both the Vistula floodplain and lateglacial-early Holocene palaeochannel systems in the Grobla Forest (Sandomierz Basin), [in:] Evolution of the Vistula river valley during the last 15000 years, part IV, Geographical Studies, Special Issue 6, pp 87-99, 1991.

[7] Kalicki T., Starkel L., Sala J., Soja R. \& Zernickaya V.P. Subboreal paleochannel system in the Vistula valley near Zabierzów Bocheński (Sandomierz Basin), [in:] Evolution of the Vistula river valley during the last 15000 years, part VI, Geographical Studies, Special Issue 9, pp 129158, 1996.

Kalicki T. The grain size of the overbank deposits as carriers of paleogeographical information, Quaternary International, vol. 72, pp 107-114, 2000.

Kalicki T. The reflection of climatic changes and human activity on sediments of small Forecarpathian tributaries of the Vistula river near Cracow, Poland, Studia Geomorphologica Carpatho-Balcanica, vol. 31, pp 129-141, 1997.

Kmietowicz-Drathowa I. Rys budowy geologicznej czwartorzędu Krakowa, Spraw. z Posiedz. Komis. Nauk. Oddz. PAN Kraków, pp 269-274, 1964.

Bąkowski K. Dawne kierunki rzek pod Krakowem, Rocz. Krakowski, vol. 5, pp 138-172, 1902.

[12] Żaki A. Badania nad przedlokacyjnym Krakowem w 1962 roku (seria X), Sprawozdania Archeologiczne, vol. 17, pp 278-287, 1965.

[13] Jamka R. Kraków w pradziejach, Biblioteka Archeologiczna, vol. 16, 1963.

[14] Mitkowski J. Kraków przed lokacją, [in:] Szkice z dziejów Krakowa, pp 7-23, 1968.

[15] Starkel L. Odbicie ekstremalnych wezbrań okresu historycznego w osadach rzecznych i stokowych w dorzeczu górnej Wisły, Acta Universitatis Nicolai Copernici, Geogr., vol. 27, no. 92, pp 13-20, 1994.

[16] Radwański K. Stosunki wodne wczesnośredniowiecznego Okołu w Krakowie, ich wpływ na topografię osadnictwa, próby powiązania tych zjawisk ze zmianami klimatycznymi, Materiały Archeologiczne, vol. 13, pp 5-40, 1972.

[17] Radwański K. Kraków przedkolacyjny, Polskie Towarzystwo Archeologiczne i Numizmatyczne, Kraków, 1975.

[18] Folk R.L. \& Ward W.C. Brazos river bar: a study of significance of grain size parameters, Journal Sedim. Petrol., vol. 27, pp 3-26, 1957.

[19] Mamakowa K. Late-glacial and Early-holocene vegetation from the territory of Kraków (Poland), Acta Paleobot., vol. 11, no. 1, pp 3-12, 1970. 